\title{
Postural load on the personnel of a Costa Rican university and implications for occupational health
}

\author{
Lourdes Arce Espinoza ${ }^{1} \&$ Julián Monge Nájera² \\ ${ }^{1}$ Servicio Médico, Universidad Estatal a Distancia, 474-2050 San Pedro, Montes de Oca, San José, Costa Rica; larce@uned.ac.cr \\ ${ }^{2}$ Vicerrectoría de Investigación, Universidad Estatal a Distancia, 474-2050 San Pedro, Montes de Oca, San José, Costa Rica; julianmonge@gmail.com
}

Recibido 28-V-2010 Corregido 5-IX-2010 Aceptado 29-IX-2010

\begin{abstract}
Repetitive movements that require considerable effort lead to structural disorders of the muscle-skeleton system. This type of highly disabling occupational diseases has been increasing in recent years, and became a major public health problem worldwide. To determine the ergonomic risk, we analyzed the postural load in 28 workers from three departments of a Costa Rican university. For this we used a widely accepted standard method, the Rapid Upper Limb Assessment (RULA). All subjects suffer excessive postural loads in arm, forearm, neck, back, legs and wrist, so we recommend urgent changes to prevent further health damage. Our results can be useful for comparative studies with other working places.
\end{abstract}

\section{KEY WORDS}

Postural load, ergonomic assessment method, muscle-skeletal disorders, occupational hazard, Costa Rica, university personnel.

\section{RESUMEN}

Los trabajos repetitivos que requieren esfuerzos considerables llegan a provocar alteraciones del aparato músculo-esquelético. Este tipo de enfermedades ocupacionales, altamente incapacitantes, ha ido en aumento en los últimos años, llegándose a considerar un problema de salud pública importante a nivel mundial. Para determinar el riesgo de sufrir alguna alteración de este tipo en tres departamentos de una universidad costarricense, hicimos un análisis de carga postural en 28 trabajadores con el método de Evaluación Rápida de Miembros Superiores (RULA por sus siglas en inglés). Todos los sujetos evaluados sufren una carga postural excesiva en brazo, antebrazo, cuello, espalda, piernas y muñeca, por lo que se requiere introducir cambios de manera urgente tanto en las posturas como en los puestos de trabajo. De América Latina se han publicado pocos estudios sobre este tema y aparentemente este es el primero que trata sobre personal universitario.

\section{PALABRAS CLAVE}

Carga postural, método de evaluación ergonómica, alteraciones músculo-esqueléticas, riesgo laboral, Costa Rica, personal universitario.
Ergonomic studies are the basis to establishment of a good relationship between humans and their working environment. In Latin America, it is a relatively new field, but it deserves attention because it can benefit employees and employers by reducing health problems and financial loss (Martinez et al. 2004).

Until recently, the majority of industrial equipment and processes were planned around machinery, without taking into account the physical characteristics of its human users: the worker had to adapt to the job, instead of adapting the job to the worker (Minaya et al. 2006). Therefore, the central principle of ergonomics in the XXI century is to adapt the equipment, tools and workplace to human needs instead (Karwowski 2005).
The new ergonomics trend in industries and offices considers the appropriate positions to prevent, or at least reduce, diseases related with poor posture, inadequate jobs, repetitive movements, work overload and physical fatigue (Apud et al. 2003, Montiel et al. 2006).

Few studies have scientifically proven a causal relationship between ergonomic failures and muscle damage, but those that meet rigorous criteria, found, for example, that repetitive work that requires strong efforts produces disorders of the muscle-skeletal system. This is especially important when it affected the tendons and tendon sheaths in hands and wrists (causing carpal tunnel syndrome, Stock 2007), because hundreds of millions of people use computer keyboards daily. For example, in the United 
States of America, muscle-skeletal disorders that result from inadequate working conditions, went from $21 \%$ to $56 \%$ over a ten year period, occupying one of the first places in occupational diseases (Montiel et al. 2006). Such disorders are highly disabling, require prolonged rest and other therapeutic care, and have a high impact on the economy (Saldívar et al. 2003).

Considering the importance of ergonomics, several risk indicators have been developed to assess the exposure of workers. Meta-analyses of studies on ergonomics have found that most of them are of poor quality (Westgaard 2010). Acceptable studies must use control groups or randomized controlled trials to identify biases and factors that confuse the analysis (Westgaard 2010). One method that allows an effective evaluation method is the Rapid Upper Limb Assessment (RULA). This method has the additional advantages that it quickly evaluates positions and limb angles, and that it considers each limb separately when determining the degree of postural load (Guillén 2006).

Here we use that method to analyze the postural load on personnel of three departments of a Costa Rican university and its implications for their occupational health. There are no equivalent previous studies in Central America, so this study is very important locally.

\section{METHODOLOGY}

\section{Subjects}

We conducted a direct assessment of all the university workplaces where strong repetitive movements are made: the Printing Department (staff: 15 workers), the Distribution Center ( 8 workers) and the General Store (5 workers).

\section{Data collection}

We applied the RULA method (Rapid Upper Limb Assessment) which was created in 1993 by Lynn McAtamney and Nigel Corlett, members of the Institute of Occupational Ergonomics at Nottingham University, England. It consists of a quick and easy evaluation of the positions of workers to determine the stresses suffered by the muscles of the upper limbs, neck, trunk and legs.

For this, we conducted a direct observation of postures, repetitive movements, forces exerted and static activity.

For the evaluation, body parts are divided into two groups. Group A includes the upper limbs (arms, forearms and wrists) and group B includes the neck, trunk and legs. Subsequently, based on the score received, we established the necessary level of intervention. Data were combined in tables to obtain the overall score where 1 is the lowest risk level and 7 the highest.

We used Excel 2008 for clustering numerical data and for subsequent analysis of variables.

\section{Ethics}

We followed all pertinent ethical guidelines described by Emanuel et al. (2000). Our study provides original and rigorously collected scientific information on a previously unknown subject; the results can be used to improve health care in the studied institution and similar environments; we only recorded patients who were properly informed about the study and accepted to participate; and no individual identities are presented or can be identified in this sample. Furthermore, the project was approved by the University Research Division, which includes ethics among its criteria; and no medical treatment was applied to any patients whatsoever.

\section{RESULTS}

All workers have more than three years in the job, their ages range between 19 and 59 years (mean 34, standard deviation 11 years), all are residents of the Greater Metropolitan Area of Costa Rica and, with one exception, all are men. Socioeconomic status and schooling is variable, 13 work as warehouse staff and 15 are equipment operators, and all finished high school education.

All staff have a RULA level of 7: they suffer excessive postural loading in the arm, forearm, neck, back, legs and wrist. They are exposed to repetitive movements, use of muscle strength, awkward postures and lifting or carrying of heavy loads; therefore they urgently require changes in working postures or in their workstations (Table 1).

\section{DISCUSSION}

In many countries, ergonomic requirements are not considered in the design and implementation of workplace activities, and conditions that violate ergonomic standards are widespread (Karwowski 2005). In addition, weight lifting and awkward postures are the main cause of consultation related with muscle-skeletal disorders, which are also the main causes of consultation in the institution studied (Arce \& Monge 2008). These highly disabling conditions, marked by slow recovery, can become chronic diseases, with serious effects on the staff's quality of life; additionally, they cause an economic loss to the 


\section{CUADRO 1}

Job description for Costa Rican university personnel studied during this project

\begin{tabular}{|c|c|c|}
\hline Job title & Description & Ergonomic hazards \\
\hline Technician & $\begin{array}{l}\text { Upload cardboard to table. Add ink to press. } \\
\text { Calibrate and check pressures. Visualize color } \\
\text { densities. Download cardboard from table. }\end{array}$ & $\begin{array}{l}\text { Uncomfortable postures. Repetitive movements. } \\
\text { Lifting loads. Poorly designed workstation. }\end{array}$ \\
\hline Operator & $\begin{array}{l}\text { Connect compressors. Calibrate units. Check } \\
\text { machine. Load units. Recharge units. Load paper. } \\
\text { Change guides. Adjust rollers. Stow product. } \\
\text { Mobilize pallets. }\end{array}$ & $\begin{array}{l}\text { Repetitive movements. Manual and mechanical } \\
\text { lifting of weights. Application of force. }\end{array}$ \\
\hline Grocer & $\begin{array}{l}\text { Load books. Stow product. Mobilize pallets. } \\
\text { Mobilize product. Load and unload product. }\end{array}$ & $\begin{array}{l}\text { Uncomfortable positions. Repetitive movements. } \\
\text { Manual and mechanical lifting of weights. } \\
\text { Application of force. }\end{array}$ \\
\hline
\end{tabular}

institution (Alonso 1999, Perucho et al. 2003, Vidaurrázaga et al. 2005, Domínguez et al. 2007).

The fact that the departments studied belong to an institution that has operated for over 30 years and yet the entire staff have an unacceptable level in the RULA scale, is significant. For this study we have avoided common methodological mistakes, by following the recommendations of Guillén (2006), Hagberg (2007), and Westgaard (2010), so we are confident to recommend urgent changes (Stock 2007) in attitudes, processes and jobs in these departments.

\section{RECOMMENDATIONS}

We recommend that the institution:

1. Develops an education and prevention plan leading to healthy posture and movements, proper weight lifting and carrying (with mechanical assistance) and inclusion of other ergonomic norms in all working stations.

2. Reviews working processes to automate and improve them.

\section{ACKNOWLEDGEMENTS}

We thank two anonymous reviewers for their excellent suggestions to improve the manuscript; René Muiños, Elver Castro, José Morales and their staff for their cooperation; and our assistant Andrea Sánchez Guevara. This study was financed by Vicerrectoría de Investigación UNED under the lead of Katya Calderón.

\section{REFERENCES}

Alonso, F. 1999. Modelo de evaluación ergonómica para la exposición a riesgos músculo-esqueléticos en miembros inferiores. MAPFRE Seguridad 107: 20-30.

Apud. E. \& F. Meyer. 2003. La importancia de la ergonomía para los profesionales de la salud. Ciencia y Enfermería 9: 15-20.

Arce L. \& J. Monge. 2008. Morbilidad y ciclos temporales en la consulta externa de una universidad costarricense de Costa Rica. Revista Ciencia del Movimiento Humano y Salud 5: 1-11.

Domínguez, M., E. Gabilondo, E. Larrañaga, E. Fernández, J. Múñoz \& F. Rico. 2007. Implicación de las personas en la evaluación de riesgos laborales. Medicina y Seguridad del Trabajo 53: 15-20.

Guillén, M. 2006. Ergonomía y relación con los factores de riesgo en salud ocupacional. Revista Cubana de Enfermería (http://scielo.sld.cu/scielo.php?script=sci_arttext\&p id=S0864-03192006000400008\&Ing=es, consultado 25 mayo 2010).

Hagberg, M. 2007. Exposure variables in ergonomic epidemiology. American Journal of Industrial Medicine 21: 91-100.

Karwowski, W. 2005. Ergonomics and human factors: the paradigms for science, engineering, design, technology and management of human-compatible systems. Ergonomics 48: 436-463

Martínez, M., J.J. Marín, R. Ros \& M. J. Bone. 2004. Sistema experto para la evaluación ergonómica y psicosocial de puestos de trabajo. Anuario de Psicología 35: 547-564.

Minaya, A., L.A., Arráez, A. Iniesta, S. O’Connor \& J. González. 2006. Diseño de un estudio ergonómico para evaluar patologías osteomusculares en puestos laborales: estudio piloto. Biomecánica 14: 64-66. 
Montiel, M., J. Romero, A.L. Palma, A.L. Quevedo, L. Rojas, B. Chacin \& Ch. Sanabria. 2006. Valoración de la carga postural y riesgo músculo-esquelético en trabajadores de una empresa metal mecánica. Salud de los Trabajadores 14:61-69.

Perucha, M. \& J. Ledezma. 2003. Evaluación de las posturas de trabajo como riesgo de carga física en el sector marítimo pesquero. Instituto Nacional de Seguridad e Higiene en el Trabajo 28: 11-15.

Saldívar A.H., D. Cruz, L. Serviere, F. Vásquez \& V. Joffre. 2003. Lumbalgia en trabajadores, epidemiología. Revista Médica 43: 203-209.
Stock, S.R. 2007. Workplace ergonomic factors and the development of muscle-skeletal disorders of the neck and upper limbs: A meta-analysis. American Journal of Industrial Medicine 19: 87-107.

Vidaurrázaga, Y., G. Damián, V. Díaz \& O. Razo. 2005. Evaluación de posturas labores en la empresa Zahori. Sociedad de Ergonomistas de México, A.C. Memorias del VII Congreso Internacional 64 -71. Universidad Autónoma de Nuevo León, Nuevo León, México.

Westgaard. R.H. 2010. RCTs of ergonomic interventions. Occupational and Environmental Medicine 67: 217-218.

Article edited by Vanessa Nielsen 